Acta vet. scand. $1986,27,540-547$.

From the Department of Epizootiology and the Bacteriological Laboratory, National Veterinary Institute, and the Department of Food Hygiene, Faculty of Veterinary Medicine, Swedish University of Agricultural Sciences, Uppsala, Sweden.

\title{
COLONIZATION OF BROILERS WITH CAMPYLOBACTER IN CONVENTIONAL BROILER-CHICKEN FLOCKS *
}

\author{
By \\ Anders Engvall, Åsa Bergqvist, Karin Sandstedt and \\ Marie-Louise Danielsson-Tham
}

\begin{abstract}
ENGVALL, A., §. BERGQVIST, K. SANDSTEDT and M.-L. DANIELSSON-THAM: Colonization of broilers with Campylobacter in conventional broiler-chicken flocks. Acta vet. scand. 1986, 27, 540-547. - Eight of 16 conventional broiler-chicken flocks examined contained Campylobacter. All isolates were identified as C. jejuni except from 1 flock were C. coli was isolated. One herd consisting of 6 different houses where Campylobacter regularly has been isolated was continuously examined. It was not possible to isolate Campylobacter from newly hatched chickens or from enviranmental samples and cloacal swabs during the 2 first weeks of growth.
\end{abstract}

Campylobacter jejuni; caecum; faeces; avian.

Campylobacter jejuni is now recognized as a significant cause of disease in humans, in many countries outnumbering Salmonella as the main bacteriological cause of diarrhea (Prescott \& Munroe 1982, Blaser et al. 1983, Shane \& Montrose 1985). Infection with $\mathrm{C}$. jejuni has been reported to occur following consumption of untreated or contaminated water (Mentzing 1981), unpasteurized milk (Robinson \& Jones 1981, Finch \& Blake 1985) and incompletely cooked meat and meat products, especilly from poultry (Blaser et al. 1983, Shane \& Montrose 1985).

Poultry has been considered to be of special significance as a reservoir for $\mathrm{C}$. jejuni and a cause of human intestinal campylobacteriosis (Norkrans \& Svedhem 1982, Christenson et al. 1983),

* This study was supported by a grant from the Elsa and Ivar Sandberg Foundation. 
and in several studies a high percentage of poultry flocks has been found to be carriers of C. jejuni, (Shanker et al. 1982, Wempe et al. 1983, Neill et al. 1985, von Altmeyer et al. 1985, Pokamunski et al. 1986). Studies by Neill et al. (1985) also indicate that $\mathrm{C}$. jejuni might have detrimental effects on the broilers.

Prevention of colonization of broilers with $\mathrm{C}$. jejuni has been discussed but has been considered difficult to achieve. However, little information is available regarding factors important for the colonization of broilers with Campylobacter. In the present study conventional Swedish broilers were surveyed for C. jejuni. In addition the pattern of colonization of $\mathrm{C}$. jejuni was investigated in 1 broiler farm where $\mathrm{C}$. jejuni regularly has been isolated.

\section{MATERIAL AND METHODS \\ Animals investigated \\ Prevalence study. The prevalence study comprised} 16 separate broiler flocks. From each flock approximately 200 broiler chickens were investigated. Flocks were mainly situated in the middle and south of Sweden. A questionnaire regarding mortality, water supply, environmental conditions etc. was sent to the owners of all investigated flocks.

Colonization pattern study. The colonization pattern study comprised 5 flocks of each 40000 broilers conventionally reared in 4 identical houses by a local former. Each house was partitioned in 2 units with a service room in common, each unit having a capacity of 20000 broilers. Broilers from each flock were sampled at their arrival to each house and thereafter weekly until slaughter. The number of samples is given in Table 1.

\section{Environmental samples investigated}

Colonization pattern study. In the colonization pattern study environmental samples were taken in empty houses the same day as broilers arrived and included 5-10 samples from waterers, $1-5$ feed samples and $2-4$ litter samples from each house. Two to 4 times during the feeding period faecal and water samples from the floor and waterers respectively were taken. The number of samples is given in Table 2. 


\section{Sampling technique}

Prevalence study. Broilers submitted for slaughter were sampled at abattoirs. Caeca were opened aseptically and caecum content from 2 birds was sampled with individual sterile cotton swabs and pooled in a tube with enrichment broth. Tubes from most sampled flocks were placed in the incubator within $6 \mathrm{~h}$ of sampling, a few within $8 \mathrm{~h}$.

Colonization pattern st udy. Newly hatched 1 day old chickens which had arrived to the farm were killed and brought to the laboratory. Before opening the abdomen chickens were washed in $40 \mathrm{ml}$ of enrichment broth which was collected in a tube. After opening of the abdomen 1 caecum and 1 egg yolk sample from each chicken were pooled in a tube with enrichment broth. During the feeding period broilers were sampled by cloacal swabbing with sterile cotton swabs and 2 swabs were pooled in a tube with enrichment broth at the farm. In the end of the feeding period a few birds were also sampled as described under prevalence study.

All samples from waterers were taken with sterile cotton swabs and placed in individual tubes with enrichment broth. Feed and litter were taken from "fodder chains" and the floor respectively in plastic bags. Each sample consisted of approximately $100 \mathrm{~g}$ and a subsample was transferred to a tube with enrichment broth at arrival to the laboratory. Droppings were sampled with sterile cotton swabs. Three swabs were pooled in a tube with enrichment broth at the farm.

\section{Media, culture technique and biochemical tests}

Enrichment broth consisted of Nutrient Broth No 2 (Oxoid CM 67), 5 \% (v/v) saponine-lysed horse blood, Preston Campylobacter selective supplement consisting of polymyxin B $5000 \mathrm{IU} / \mathrm{l}$, trimethropim $10 \mathrm{mg} / \mathrm{l}$, riphampicin $10 \mathrm{mg} / \mathrm{l}$ and actidion 100 mg/l (Oxoid SR 117); selective agar consisted of agar base (Oxoid CM 689), $5 \%$ (v/v) saponine-lysed horse blood and selective supplement (Oxoid SR 117). All enrichment broth tubes and selective agar plates were incubated microaerobically in anaerobic jars (BBL) equipped with Campy Pak or with Gas Pak (BBL) without catalysts. Tubes with broth were incubated for $24 \mathrm{~h}$ in $42^{\circ} \mathrm{C}$ after which agar plates were ionculated with $10 \mu \mathrm{l}$ using a calibrated loop and incubated for $48 \mathrm{~h}$ in $42^{\circ} \mathrm{C}$. Suspected 
Campylobacter colonies were subjected to light and phase contrast microscopy of Gram-stained smears and saline suspensions respectively. Gram-negative, curved bacteria which showed characteristic movements were considered as potential Campylobacters. Colonies of those isolates were subcultured onto horse blood agar plates, which were incubated under microaerobic conditions as stated above for $24-48 \mathrm{~h}$ at $42^{\circ} \mathrm{C}$. The colonies were tested for oxidase and catalase activity and if positive also for hippurate hydrolysis according to Lior (1984). Hippurate positive isolates were condisered C. jejuni, those hippurate negative C. coli.

\section{RESULTS}

Prevalence study

All isolates were C. jejuni except from 1 farm where both C. jejuni and C. coli were found.

Campylobacter was isolated from 8 of 16 flocks surveyed. From 2 of these flocks only 2 pooled samples showed growth of C. jejuni while in the other 6, C. jejuni was isolated from 83 to $100 \%$ of pooled samples investigated. The questionnaire was answered by all except 2 farmers whose broilers were free from Campylobacter. The mean number of broilers in investigated flocks were 21,638 and 33,354 for Campylobacter-free and Campylobacter-contaminated flocks respectively. Total mortality was slightly higher, though not significantly so in Campylobactercontaminated $(3.22 \%)$ as compared to Compylobacter-free $(2.70 \%)$ flocks. No farmer had noticed rodents or wild birds in investigated flocks except for rodents in 1 Campylobacter-contaminated flock. All farmers with Campylobacter-free and 6 with Campylobacter-contaminated flocks had water from drilled wells or municipal water while 2 farmers with Campylobactercontaminated flocks used untreated water from local lakes. C. coli was isolated from 1 of these 2 flocks.

\section{Colonization pattern study}

Campylobacter was neither isolated from environmental samples taken from empty broiler houses nor from newly hatched chickens. Isolations of Campylobacter from broilers and environmental samples during feeding periods are summerzed in Tables 1 and 2 respectively. Campylobacter was not isolated until week 3 from birds or environmental samples from any house or flock 
T a b l e 1. Isolation of Campylobacter from 5 broiler flocks in 4 different houses.

\begin{tabular}{lccccccc}
\hline & \multicolumn{7}{c}{ Age of broilers in weeks } \\
\cline { 2 - 8 } Flock & $0^{\mathrm{a}}$ & 1 & 2 & 3 & 4 & 5 & 6 \\
\hline $\mathrm{A}_{1} \mathrm{c}$ & $0 / 10^{\mathrm{b}}$ & nd & $0 / 12$ & $0 / 10$ & nd & $8 / 17$ & $30 / 30$ \\
$\mathrm{~A}_{2} \mathrm{c}$ & $0 / 10$ & $0 / 15$ & $0 / 15$ & $0 / 15$ & $15 / 15$ & nd & nd \\
$\mathrm{B}$ & $0 / 10$ & $0 / 15$ & $0 / 15$ & $0 / 15$ & $4 / 29$ & nd & nd \\
$\mathrm{C}$ & $0 / 10$ & $0 / 17$ & $0 / 15$ & $15 / 15$ & nd & nd & nd \\
$\mathrm{F}$ & $0 / 10$ & $0 / 10$ & $0 / 10$ & $19 / 19$ & $17 / 17$ & $23 / 29$ & nd \\
\hline
\end{tabular}

nd: not done.

a Newly hatched 1 day old chickens.

b Number of Campylobacter positive broilers through number of broilers tested.

c Same house, different feeding periods.

T a b l e 2. Isolation of Campylobacter from environmental samples. (Flocks and houses are the same as in Table 1.)

\begin{tabular}{|c|c|c|c|c|c|}
\hline \multirow{2}{*}{ Flock } & \multirow{2}{*}{$\begin{array}{l}\text { Type of } \\
\text { sample }\end{array}$} & \multicolumn{4}{|c|}{ Age of broilers in weeks } \\
\hline & & 1 & 2 & 3 & 4 \\
\hline \multirow[t]{2}{*}{$A_{1}$} & waterer & nd & $0 / 9 \mathrm{a}$ & $0 / 5$ & nd \\
\hline & droppings & nd & $0 / 4$ & $0 / 3$ & nd \\
\hline \multirow[t]{2}{*}{$\mathrm{A}_{2}$} & waterer & $0 / 3$ & $0 / 5$ & $0 / 5$ & $5 / 5$ \\
\hline & droppings & $0 / 3$ & $0 / 4$ & $0 / 2$ & $5 / 5$ \\
\hline \multirow[t]{2}{*}{ B } & waterer & $0 / 5$ & $0 / 5$ & $0 / 5$ & nd \\
\hline & droppings & $0 / 1$ & $0 / 2$ & $0 / 4$ & nd \\
\hline \multirow[t]{2}{*}{ C } & waterer & $0 / 5$ & $0 / 5$ & nd & $5 / 5$ \\
\hline & droppings & $0 / 1$ & $0 / 2$ & nd & $3 / 3$ \\
\hline \multirow[t]{2}{*}{ F } & waterer & $0 / 8$ & $0 / 10$ & $3 / 3$ & $5 / 5$ \\
\hline & droppings & $0 / 5$ & $0 / 2$ & $1 / 1$ & $2 / 2$ \\
\hline
\end{tabular}

nd. not done.

a Number of Campylobacter positive samples through number of samples tested.

involved. In the house of flock B Campylobacter was not isolated from any environmental samples (Table 2), which happens to coincide with a low isolation rate from broilers of that flock.

\section{DISCUSSION}

The present study clearly indicates that many Swedish broilers are contaminated with Campylobacter jejuni during growth. Data from earlier studies (Norberg 1981, Norkrans \& 
Svedhem 1982, Christenson et al. 1983) have indicated this even though investigations of individual broilers at farms or at slaughter were not performed.

Neill et al. (1984) showed that early introduction of C. jejuni in broiler flocks caused significantly higher mortality compared to other flocks. In the present study mortality was higher in Campylobacter-contaminated flocks. The difference was small however. Other factors such as flock size, hygiene standard, handling practice etc. might also coincide with the presence of Campylobacter and influence mortality.

From the questionnaire it was not possible to draw definite conclusions regarding the source of contamination with the possible exception of 2 flocks, where the source might be identified as drinking water which was taken from lakes.

All investigated flocks but 1 had virginiamycin as growth promoting antibiotic added to the food during the feeding period. Seemingly this small amount $(10 \mathrm{ppm})$ of antibiotic has not affected the ability of Campylobacter to colonize broilers.

The origin of Campylobacter colonizing broilers is obscure. In farms not changing litter between flocks, litter is a probable source (Montrose et al. 1985). However, in Sweden as in many other countries, broiler houses, after emptying, are extensively cleaned and disinfected. This procedure will probably kill most, if not all, Campylobacter present. Newly hatched chickens were Campylobacter-negative in the present study. The same result has been obtained in other studies (Neill et al. 1984, von Altmeyer et al. 1985, Pokamunski et al. 1986), and experimental data support this (Clark \& Bueschkens 1985, Neill et al. 1985, Clark \& Bueschkens 1986). Possibly, the source of contamination should be looked for in the environment outside or close to the house e.g. rodents or insects. Another possible way is through cross-contamination by staff or equipment.

The time of detection of Campylobacter in different houses varied from 3 to 5 weeks. Approximately the same time has been reported by others (von Altmeyer et al. 1985, Pokamunski et al. 1986) even though in some cases Campylobacter was found withinin a few days (Neill et al. 1984). The reason for this probably is that a too small number of samples are taken to detect Campylobacter during early stages of spread or that Campylobacter is introduced late and spreads explosively in the house. A contributory factor in such an explosive spread could be air- 
borne spreading. In fact in the colonization study we found that Campylobacter was present in the air in some houses with Campylobacter-contaminated broilers as evidenced by Campylobacter-positive air-samples taken in these houses (unpublished results).

Waterers and droppings from the floor seem to be good indicators of the presence of Campylobacter in broiler flocks.

\section{ACKNOWLEDGEMENTS}

We thank G. Blomgren, E. Tysén, M. Wold-Troell and A. Landén for excellent technical assistance.

\section{REFERENCES}

von Altmeyer, M., P. Krabisch \& P. Dorn: Zum Vorkommen und zur Verbreitung von Campylobacter jejuni/coli in der Jungmastgeflügel-Produktion. (Occurrence and distribution of Campylobacter jejuni/coli in broiler-chicken herds). Dtsch. tierärztl. Wschr. 1985, 92, 449-504.

Blaser, M. J., D. N. Taylor \& R. A. Feldman: Epidemiology of Campylobacter jejuni infections. Epidemiological Reviews 1983, 5, 157 $-176$.

Christenson, B., A. Ringner, C. Blücher, H. Billaudelle, K. N. Gundtoft, G. Eriksson \& M. Böttiger: An outbreak of Campylobacter enteritis among the staff of a poultry abattoir in Sweden. Scand. J. infect. Dis. 1983, 15, 167-172.

Clark, A. G. \& D. H. Bueschkens: Laboratory infection of chicken eggs with Campylobacter jejuni by using temperature of pressure differentials. Appl. Environ. Microbiol. 1985, 49, 1467-1471.

Clark, A. G. \& D. H. Bueschkens: Survival and growth of Campylobacter jejuni in egg yolk and albumen. J. Food Protect. 1986, $49,135-141$.

Finch, M.J.\& P. A. Blake: Foodborne outbreaks of Campylobacteriosis: The United States experience 1980-1982. Amer. J. Epidemiol. $1985,122,262-268$.

Lior, H.: New extended biotyping scheme for Campylobacter jejuni, Campylobacter coli, and "Campylobacter laridis". J. clin. Microbiol. 1984, 20, 636-640.

Montrose, S. M., S. M. Shane \& K. S. Harrington: Role of litter in the transmission of Campylobacter jejuni. Avian Dis. 1984, 29, 392 399.

Neill, S. D., J. N. Campell \& J.J.O'Brien: Egg penetration by Campylobacter jejuni. Avian Pathol. 1985, 14, 313-320.

Neill, S. D., J. N. Campell \& J. A. Greene: Campylobacter species in broiler chickens. Avian Pathol. 1984, 13, 777-785.

Norberg, P.: Enteropathogenic bacteria in frozen chicken. Appl. Environ. Microbiol. 1981, 42, 32—42. 
Norkrans, G. \& A. Svedhem: Epidemiological aspects of Campylobacter jejuni enteritis. J. Hyg. (Camb.) 1982, 89, 163-170.

Pokamunski, S., N. Kass, E. Borochovich, B. Marantz \& M. Rogol: Incidence of Campylobacter in broiler flocks monitored from hatching to slaughter. Avian Pathol. 1986, 15, 83-92.

Prescott, J. F. \& D. L. Munroe: Campylobacter jejuni enteritis in man and domestic animals. J. Amer. vet. med. Assoc. 1982, 181, $1524-1530$.

Shane, S. M. \& M. S. Montrose: The occurrence and significance of Campylobacter jejuni in man and animals. Vet. Res. Comm. 1985, 9, 167-199.

Shanker, S., J. A. Rosenfield, G. R. Davey \& T. C. Sorrell: Campylobacter jejuni: Incidence in processed broilers and biotype distribution in human and broiler isolates. Appl. Environ. Microbiol. 198 ,243, 1219-1220.

Wempe, J. M., C. A. Genigeorgis, T. B. Farver \& H. I. Yusufu: Prevalence of Campylobacter jejuni in two California chicken processing jlants. Appl. Environ. Microbiol. 1983, 45, 355—359.

\section{SAMMANFATTNING \\ Förekomst av Campylobacter hos konventionellt uppfödd slaktkyckling.}

Hos åtta av 16 undersökta slaktkycklingbesättningar påvisades förekomst av Campylobacterbakterier. Campylobacter jejuni påvisades i alla campylobacterpositiva besättninger. Från en av dessa påvisades också Campylobacter coli. En besättning, där Campylobacterbakterier regelmässigt påvisats, utvaldes för närmare undersökningar. Resultaten av dessa undersökningar visade att Campylobacterbakterier ej kunde påvisas hos nykläckta kycklingar eller från kloak- och miljöprover under de första två uppfödningsveckorna.

(Received August 4, 1986).

Reprints may be requested from: Anders Engvall, the Department of Epizootiology, National Veterinary Institute, S-750 07 Uppsala, Sweden. 